\title{
Rearrangement of the $\beta$ Chain of the T Cell Antigen Receptor and Immunoglobulin Genes in Lymphoproliferative Disorders
}

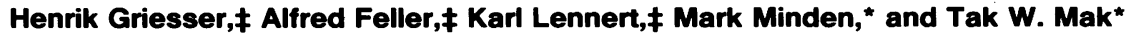 \\ *Ontario Cancer Institute, Departments of Medical Biophysics and Immunology, University of Toronto, Toronto, Ontario, Canada \\ M4X 1K9; and ¥The Institute of Pathology, Christian Albrecht University, D2300 Kiel, Federal Republic of Germany
}

\begin{abstract}
55 samples representing Hodgkin's and non-Hodgkin's lymphoma and other hyperplastic lesions of the lymph node were examined for rearrangement of the $\beta$ chain of the $T$ cell antigen receptor (TcR) and Ig genes. In non-Hodgkin's lymphoma, rearrangement of TcR $\beta$ was found in all 14 T cell lymphomas and in two of the seven $B$ cell lymphomas. Ig gene rearrangement was found in none of the $14 \mathrm{~T}$ cell lymphomas and in all seven B cell lymphomas.

We also examined DNA from lymph nodes in which the lineage of the malignant cell is not clear. Rearrangement of TcR $\beta$ was found in all five lymphoepitheloid cell (Lennert's) lymphomas; four of eight Hodgkin's lymphomas; seven of ten Ki $\mathbf{1}^{+}$ lymphomas; and all nine cases of angioimmunoblastic lymphadenopathy (AIL). Ig gene rearrangement was found in none of five lymphoepitheloid cell lymphomas; none of eight Hodgkin's lymphomas; three of ten $\mathrm{Ki} \mathrm{1}^{+}$lymphomas; and four of nine cases of AIL.

These findings indicate that genetic studies of $T c R$ and Ig genes are useful in identifying the presence of a clonal population in a lymph node, in determining the extent of the clonal population, and aid in identifying lineage. Of special interest was the finding that some cases of Hodgkin's lymphoma and AIL contain clonal rearrangement of the TcR genes, which suggests that in those cases the malignant cells may be of $T$ cell origin.
\end{abstract}

\section{Introduction}

The diagnosis and classification of lymphomas and other proliferative diseases of the lymph node have traditionally been based on morphological and histochemical criteria. The introduction of immunological techniques, particularly monoclonal antibodies, has led to a more precise classification of malignant lymphomas $(1,2)$. The clinical utility of a combined morphologic and immunologic classification of lymphomas is borne out by the observation that prognosis and optimal therapy differs according to the subtype (3).

Despite these advances, there continue to be major problems in the classification and diagnosis of lymphoid neoplasms composed predominantly of $T$ cells due to the inability to identify clonal populations of $\mathrm{T}$ cells. In addition, the cellular origin of lymphoproliferative disorders such as Hodgkin's disease, lymphoepitheloid cell lymphoma (Lennert's lymphoma), and angioimmunoblastic lymphoadenopathy (AIL)'/lymphogranu-

Received for publication 5 March 1986 and in revised form 5 June 1986.

1. Abbreviations used in this paper: AIL, angioimmunoblastic lymphadenopathy; HR, hyperimmune response; TcR, T cell antigen receptor.

J. Clin. Invest.

(c) The American Society for Clinical Investigation, Inc.

$0021-9738 / 86 / 11 / 1179 / 06 \$ 1.00$

Volume 78, November 1986, 1179-1184 lomatosis X, remains elusive. Recently, molecular probes have been used to aid in the diagnosis and classification of lymphomas (4-6). For example, some lymphomas lacking both surface and cytoplasmic Ig have been classified as B cell lymphomas based on the presence of a clonal rearrangement of the Ig genes (6). The cloning of the $\beta$ chain of the T cell antigen receptor (TcR) (7), has facilitated the investigation of T cell-related disorders $(8-12)$, as it is now possible to recognize clones of $\mathrm{T}$ cells by the unique rearrangement of the TcR $\beta$ gene. In this study we have used probes to the immunoglobulin heavy and $\kappa$-light chain genes and to the $\mathrm{TcR}$ gene to examine representative samples of DNA from each of the major categories of lymphoma. DNA from lymph nodes involved with Hodgkin's disease, AIL, AILlike hyperimmune response (HR) (13), Lennert's lymphoma, and $\mathrm{Ki} \mathrm{l}^{+}$lymphoma were also studied. Our results further demonstrate the utility of a molecular approach in evaluating lympho-hematopoietic neoplasms. In addition, we report the finding of clonal populations of T cells in AIL, Lennert's lymphoma, $\mathrm{Ki}^{+}$lymphoma, and some cases of Hodgkin's disease.

\section{Methods}

Tissues and diagnosis. Since 1983 a portion of a lymph node obtained for diagnostic purposes has been snap frozen and stored at $-70^{\circ} \mathrm{C}$ at the Institute of Pathology, Kiel. The cases were classified histologically by examination of conventionally processed paraffin-embedded tissue. Tumors were evaluated by immunoenzymatic techniques using panels of monoclonal antibodies and characterized as being of $B$ cell or non-B cell origin according to previously described criteria (14). Included in the present study were 14 samples of $T$ cell lymphoma; seven samples of B cell lymphoma; eight samples of Hodgkin's disease; five samples derived from lymph nodes classified as Lennert's lymphoma; 10 samples from lymph nodes containing cells characteristic of non-Hodgkin's lymphoma, but stained positively with the monoclonal antibody $\mathrm{Ki} 1(\mathrm{Ki}$ $1^{+}$lymphoma) (see Results); nine samples of lymph nodes diagnosed as AIL; and two samples diagnosed as representing AIL-like HR (13). Granulocytes were obtained from the peripheral blood of normal volunteers. All samples were obtained with informed consent.

Extraction of DNA. DNA was prepared as described (15). Lymph nodes were thawed quickly and a single cell suspension prepared by passing the tissue through a fine-mesh wire screen. Cells were washed twice in phosphate-buffered saline, resuspended in TNE (10 mM Tris, $100 \mathrm{mM} \mathrm{NaCl}$, and $1 \mathrm{mM}$ EDTA [pH 9.0]), and added to an equal volume of TNE containing proteinase $\mathrm{K}(400 \mu \mathrm{g} / \mathrm{ml})$ and $1 \% \mathrm{NaDodSO}_{4}$. The suspension was incubated for $12-16 \mathrm{~h}$ at $37^{\circ} \mathrm{C}$. DNA was then extracted once with phenol/chloroform/lisoamyl alcohol and several times with chloroform/isoamyl alcohol and then precipitated with isopropanol. The DNA was resuspended in $10 \mathrm{mM}$ Tris and $1 \mathrm{mM}$ EDTA (pH 7.5). The concentration and purity were determined by spectrophotometry.

Southern gel analysis. DNA was cut with one of the restriction enzymes, EcoRI, BamHI, or Hind III according to the recommendations of the supplier. Digested DNA was separated on $0.7-0.9 \%$ agarose gels and transferred to nitrocellulose paper according to Southern (16). The filters were hybridized in $5 \times \mathrm{SSC}(0.75 \mathrm{M} \mathrm{NaCl}$ and $0.075 \mathrm{M}$ sodium citrate [pH 7.0]), $0.1 \% \mathrm{NaDodSO}_{4}, 0.02 \%$ Ficoll, $0.02 \%$ bovine serum albumin and $0.02 \%$ polyvinylpyrrolidone containing sonicated salmon 
Table I. Rearrangement of $T c R_{\beta}$ and Ig Genes in non-Hodgkin's Lymphoma, and Other Proliferative Diseases of the Lymph Node

\begin{tabular}{|c|c|c|c|c|c|c|}
\hline Diagnosis (14) & No. of patients & $\mathrm{TcR}_{\boldsymbol{B}}$ & $\mathrm{Ig}_{\mathrm{HC}}+\mathbf{I g}_{\mathrm{G}}$ & $\mathrm{TcR}_{\boldsymbol{B}}+\mathrm{Ig}_{\mathrm{HC}}$ & $\mathrm{TcR}_{\boldsymbol{B}}+\mathrm{Ig}_{\mathrm{HC}+\mathrm{K}}$ & Germline \\
\hline T cell lymphoblastic lymphoma & 2 & 1 & - & - & - & 1 \\
\hline Peripheral T cell lymphoma & 12 & 12 & - & - & - & - \\
\hline B cell lymphoma & 7 & - & 5 & - & 2 & - \\
\hline Lennert's lymphoma & 5 & 5 & - & - & - & - \\
\hline Hodgkin's lymphoma & 8 & 4 & - & - & - & 4 \\
\hline $\mathrm{Ki} 1^{+}$lymphoma & 10 & 4 & - & 3 & - & 3 \\
\hline AIL & 9 & 5 & - & 3 & 1 & - \\
\hline AIL-like HR & 2 & - & - & - & - & 2 \\
\hline
\end{tabular}

$\mathrm{TCR}_{\beta}, \mathrm{T}$ cell receptor $\beta$ chain; $\operatorname{Ig}_{\mathrm{HC}}$, immunoglobulin heavy gene; $\operatorname{Ig}_{\mathrm{K}}, \mathrm{Ig} \mathrm{K}$-light chain gene.

sperm DNA $(100 \mu \mathrm{g} / \mathrm{ml})$ and radioactive probe $\left(5 \times 10^{6} \mathrm{cpm} / \mathrm{ml}\right)$. Hybridization was at $65^{\circ} \mathrm{C}$ for $24 \mathrm{~h}$. Filters were then washed to a final wash of $0.1 \times$ SSC and $0.1 \%$ SDS at $65^{\circ} \mathrm{C}$ and autoradiographed for 24 $\mathrm{h}-8 \mathrm{~d}$ at $-70^{\circ} \mathrm{C}$ with an intensifying screen. The three probes used in this study were an Ig heavy chain joining region $\mathrm{J}_{\mathrm{H}}$ probe (17), an Ig $\kappa$ chain constant region $C_{k}$ probe (18), and a TcR $\beta$-chain probe (Jurkat $\beta 2)$ (19). The probes were made radioactive by nick translation with $\alpha$ ${ }^{32} \mathrm{P} \mathrm{dCTP}(20)$. Rearrangement was scored by the presence of a new band and/or the deletion of the germline band.

\section{Results}

To demonstrate the utility of determining the structure of the Ig and TcR genes in classifying lymphomas and to determine the clonal nature of other proliferative diseases of the lymph node, we have examined the structure of $\operatorname{TcR} \beta$ chain, Ig heavy chain, and $\kappa$-light chain gene in 55 lymphoma samples (seven $B$ cell and 48 non-B cell lymphomas). The diagnosis of these samples according to morphological, histological, and immunological approaches is summarized in Table I. A summary of the rearrangement data from all the samples is given in Table I and is discussed below.

$T$ cell lymphoma. DNA from lymph nodes of 14 patients with $\mathrm{T}$ cell lymphoma was examined. Two lymphomas showed the morphological and immunological phenotype of T lymphoblastic (thymic and pre-thymic) lymphomas. 12 cases belonged to the group of peripheral $\mathrm{T}$ cell lymphomas; there were six cases of $\mathrm{T}$ zone lymphoma, one case of cutaneous pleomorphic T cell lymphoma (non-mycosis fungoides), and five cases of immunoblastic lymphoma (one case was a high-grade malignant end stage of Lennert's lymphoma). All $14 \mathrm{~T}$ cell lymphomas showed prominant clonal rearrangement involving either $\mathrm{C}_{\beta 1}$ or $\mathrm{C}_{\beta 2}$ gene regions (10). However, for one sample two different regions of the same lymphnode were examined. One area contained T3-positive cells, whereas the other area contained T3negative, T11-positive cells. The sample prepared from the T3positive region did not show rearrangement of $\mathrm{TcR} \beta$ gene (Fig. $3 a$, lane 5), whereas the sample prepared from the T3-negative. T11-positive region did show rearrangement of $\operatorname{TcR} \beta$ (data not shown). None of the samples exhibited rearrangement of either of the immunoglobulin genes tested (Fig. 1).

$B$ cell lymphoma. (Fig. 1) Seven B cell lymphoma samples were examined. In all cases there was a population of cells that were monoclonal for either $\kappa$ or $\lambda$ light chains. In five of the cases the monoclonal $B$ cell represented the vast majority of the cells. A number of different morphologies were present in this group; one centroblastic centrocytic, one centrocytic lymphoma, one B CLL, and two high-grade malignant B cell lymphomas (otherwise unclassified). Two of the cases contained relatively equal proportions of atypical $\mathrm{T}$ cells as well as a population of monotypic B immunoblasts. On morphologic grounds, these last two cases could be interpreted as either a B cell lymphoma with a reactive $T$ cell population or a $T$ cell lymphoma with a monoclonal $B$ cell proliferation induced by the $T$ cells.

In all seven cases there was rearrangement of both the heavy chain and $\kappa$-light chain genes. The TcR $\beta$-chain genes were also found to be rearranged in two samples diagnosed as germinal center derived malignant lymphoma, (one of centroblastic/centrocytic and another of centrocytic type) (Figs. 1 and $4 a$, lane 2). The intensity of the rearranged Ig and TcR $\beta$-chain gene were roughly equal. No TcR gene rearrangement was detected in the two cases containing atypical $\mathrm{T}$ cells.

Lennert's lymphoma. (Fig. 2) The lesion of Lennert's lymphoma is characterized by a high content of epitheloid cells and some large blast cells dispersed among atypical lymphocytes. Some of these large blast cells have the typical appearance of Reed-Sternberg cells and at one time this lymphoma was felt to be a special variant of Hodgkin's disease $(21,22)$. DNA from all five cases of Lennert's lymphoma examined with the TcR $\beta$ probe revealed both a germline band and a prominent rearranged

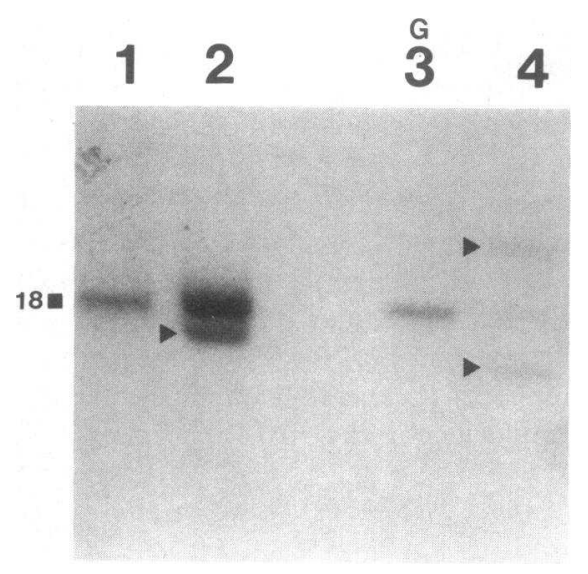

Figure 1. Southern blot of genomic DNA digested with the restriction enzyme Eco R1 and hybridized with an Ig HC probe. Lane 1, peripheral T cell lymphoma; lane 2, B cell lymphoma of the centroblastic/ centrocytic type; lane 3, granulocytes; and lane 4, B cell lymphoma of the centrocytic type. $\square$, germline band. $\triangleright$, rearranged bands. The molecular weight of the germline band is indicated in kilobases. 


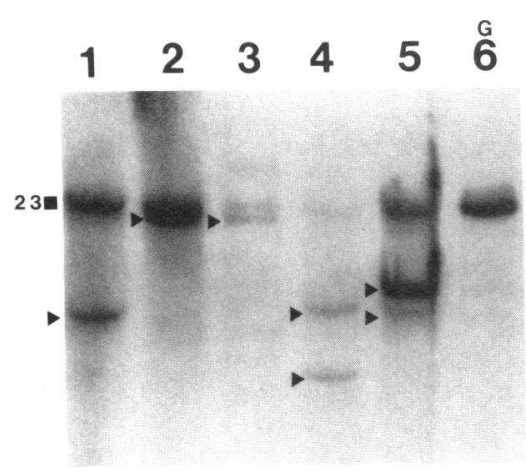

Figure 2. Southern blot of genomic DNA from lymph nodes of patients with lymphoepitheloid (Lennert's) lymphoma digested with $\mathrm{Bam} \mathrm{HI}$ and hybridized to the TcR $\beta$ probe. Lanes $1-$ 5 , tumor DNA; lane 6, granulocyte DNA. a, germline band. $\downarrow$, rearranged bands. The molecular weight of the germline band is in kilobases.

band (Fig. 2). In case 5, two rearranged bands of different intensities were seen. No rearrangement of the Ig genes was found.

Non-Hodgkin lymphoma containing large anaplastic $\mathrm{Ki}^{+}$

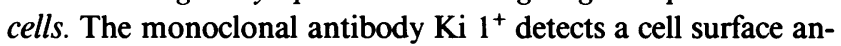
tigen present on Reed-Sternberg cells in Hodgkin's disease, activated normal $\mathrm{T}$ lymphocytes, and HLA-DR ${ }^{+}$lymphoma cells in some large cell anaplastic lymphomas (23); the latter are des-

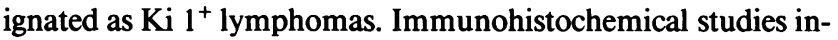
dicate that these lymphomas are mostly of $\mathrm{T}$ cell origin, sometimes of B cell origin, and rarely of histiocytic origin.

10 samples were examined for gene rearrangement (Fig. 3). Immunologic characterization revealed nine to be positive for $\mathrm{T}$ cell markers and one for B cell markers (T015 positive, Ig negative). The results of the molecular studies are summarized in Table 1 and illustrated in Fig. $3 a$ (lanes 6 and 7). Seven of the 10 samples contained prominent rearrangements of the TcR $\beta$ gene. Three of these seven samples also had rearrangement of the heavy chain Ig genes but not the $\kappa$-light chain genes (Fig. 4 $b$ ); the intensity of the TcR and Ig gene rearrangements were approximately equal. In the case found to be of $B$ cell type by immunocytochemistry, rearrangement of TcR $\beta$ and Ig heavy chain, but not light chain genes, was observed. In three samples there was no rearrangement of TcR $\beta$ or Ig genes.

$A I L$ and AIL-like HR. AIL consists of two entities: AIL ([24, 25] or Lymphogranulomatosis $X$ [26]), and the AIL type of peripheral $\mathrm{T}$ cell lymphoma (27). Both lesions are characterized by $\mathrm{T}$ cells with a variegated cytomorphology, a polyclonal mixture of plasma cells and immunoblasts, frequent infiltration by eosinophils, and a high number of epitheloid venules (arborizing vessels). The germinal centers lack the normal mixture of centroblasts and centrocytes and instead contain a strong proliferation of dendritic reticulum cells. In some cases it is possible to recognize the lesion as a $T$ cell neoplasia based on the presence of a large number of anaplastic $T$ cells or chromosomal abnormalities $(28,29)$; however there are many cases in which this is not possible. HR has many of the characteristics of AIL except that in addition to the typical lesion of AIL there is a strong follicular hyperplasia.

DNA from nine cases of AIL were examined for gene rearrangement. Rearrangement of TcR $\beta$ was found in all cases (Fig. 4 ); four of these nine samples showed rearrangement of the Ig heavy chain gene (Fig. $4 b$ ) and one of these four samples showed rearrangement of the $\kappa$-light chain gene (data not shown). No rearrangements were seen in the two cases of HR.

Hodgkin's disease. The pathologic lesion of Hodgkin's disease is represented by several different morphologies; the unifying feature of these varying morphologies is the presence of the so- called Reed-Sternberg cell (a cell whose own origin is a matter of debate). Accordingly, histological diagnosis of Hodgkin's disease may be both difficult and controversial.

DNA from eight biopsy specimens diagnosed as Hodgkin's disease were studied for gene rearrangement. In four of the cases, in addition to the $\operatorname{TcR} \beta$ germline band, a faint $\mathrm{TcR} \beta$ rearranged band was evident (Fig. 5, $a$ and $b$ ). In one case in which there were $50 \%$ Reed-Sternberg cells, no rearrangement of $\mathrm{TcR} \beta$ was seen. No rearrangement of the Ig genes was detected in any of the samples.

\section{Discussion}

In this paper we report the analysis of the structure of the Ig and TcR $\beta$ chain genes of 55 samples of DNA from lymph nodes of patients with malignant lymphoma and other proliferative dis-
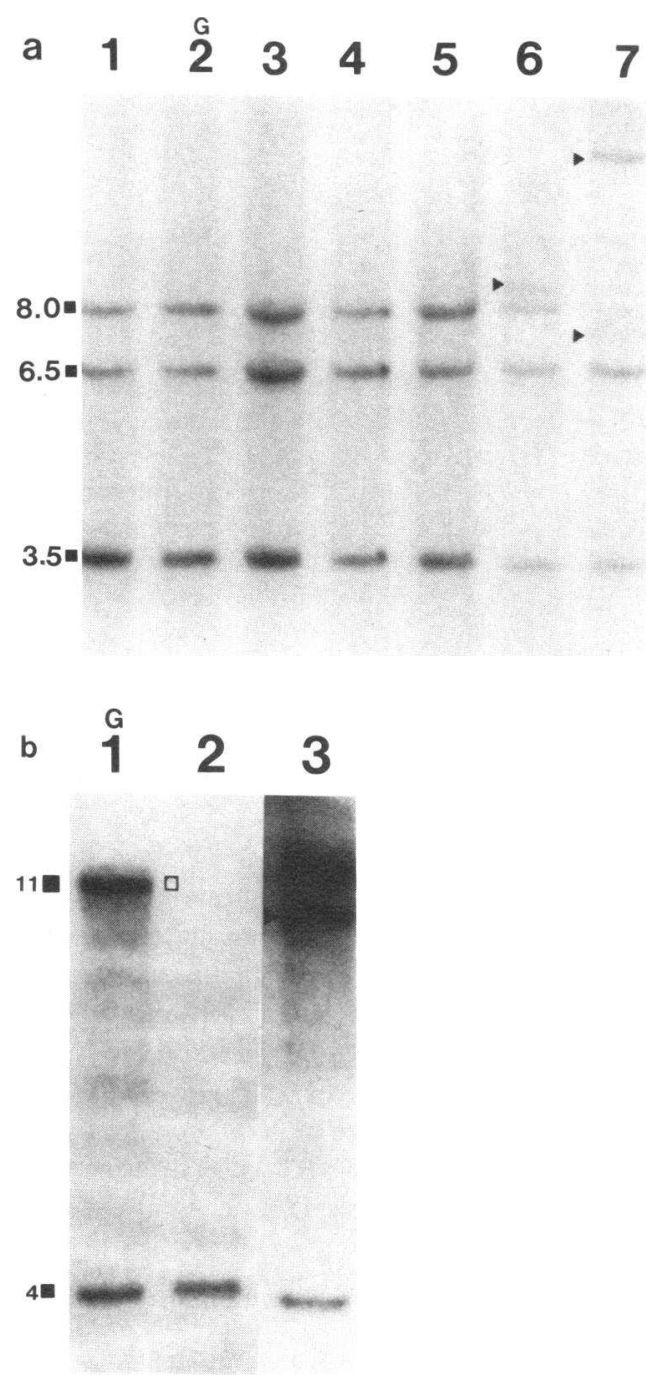

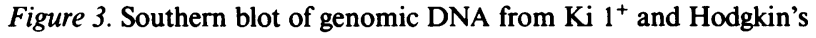
lymphomas hybridized to TcR $\beta$ probe. (a) DNA digested with Hind III: Hodgkin's disease lane 1, 3, and 4; T lymphoblastic lymphoma

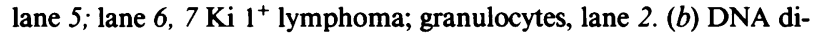
gested with Eco R1: granulocytes, lane $1 ; \mathrm{Ki} 1^{+}$lymphoma, lanes 2 and 3. $m$, germline band. $\downarrow$, rearranged bands. The molecular weight of the germline band is in kilobases. 

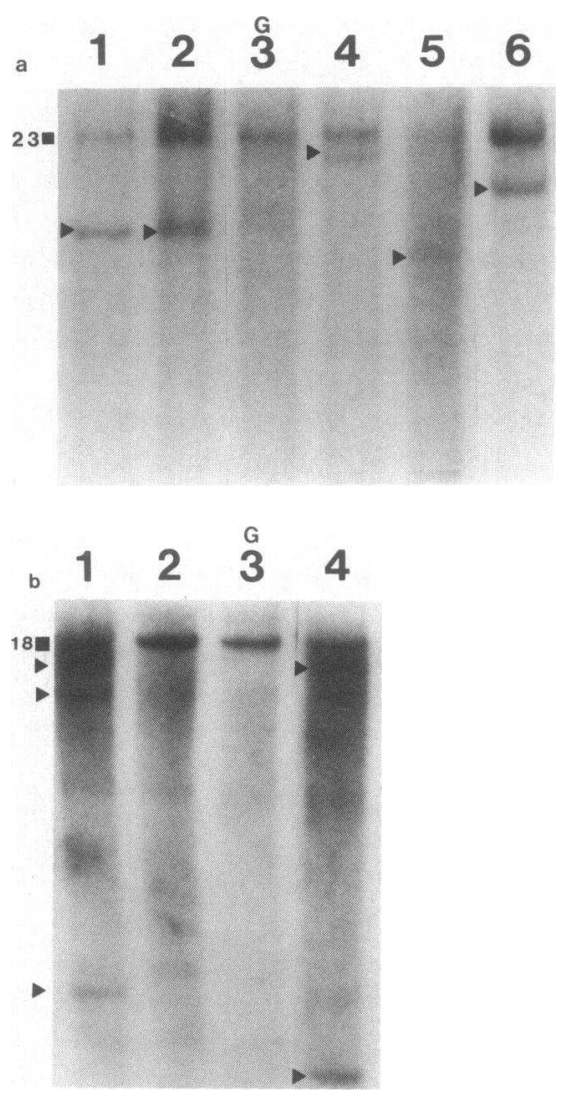

Figure 4. Southern blot of genomic DNA. (a) DNA digested with Bam $\mathrm{H} 1$ and hybridized with TcR $\beta$. Granulocytes, lane 3; angioimmunoblastic lymphadenopthy, lanes 1, and 4-6; and B cell lymphoma, centroblastic/centrocytic type, lane 2. (b) DNA digested with Eco R1 and hybridized with $\mathbf{I g}_{\mathrm{HC}}$. Granulocytes, lane 3; and angioimmunoblastic lymphadenopathy, lanes 1,2 , and 4 . $₫$, germline band. $\downarrow$, rearranged bands. The molecular weight of the germline band is in kilobases.

eases of the lymph node. We have confirmed the results of previous studies that demonstrate the usefulness of these probes for the detection of clonal populations of $B$ and $T$ cells in pathological lymph nodes (4-6, 8-12). Like others, we have observed the presence of rearrangement of both the immunoglobulin and TcR $\beta$ chain genes in DNA from the same biopsy specimen (12, 30). In addition, we have extended previous observations by demonstrating the presence of clonal populations of $\mathrm{T}$ cells in AIL, Ki $1^{+}$lymphomas, Lennert's lymphoma, and Hodgkin's disease.

In the group of disorders diagnosed as $\mathrm{T}$ cell lymphomas by morphologic and immunologic criteria, all 14 cases demonstrated clonal rearrangement of the $\mathrm{TcR}$. No rearrangement of the $\mathrm{Ig}$ genes was found. The finding in one case that samples derived from two different areas of the lymphnode may give totally different results indicates the importance or ensuring that the tissue being analyzed for gene rearrangement contains the malignant population of cells.

All samples diagnosed as B cell lymphomas by morphologic and immunologic criteria contained clonal rearrangements of both the heavy and light chain genes. In addition, rearrangement of the TcR was found in two samples of germinal center-derived B cell lymphomas. A similar observation has previously been made in lymphomas of B cell origin (12), non-B non-T acute

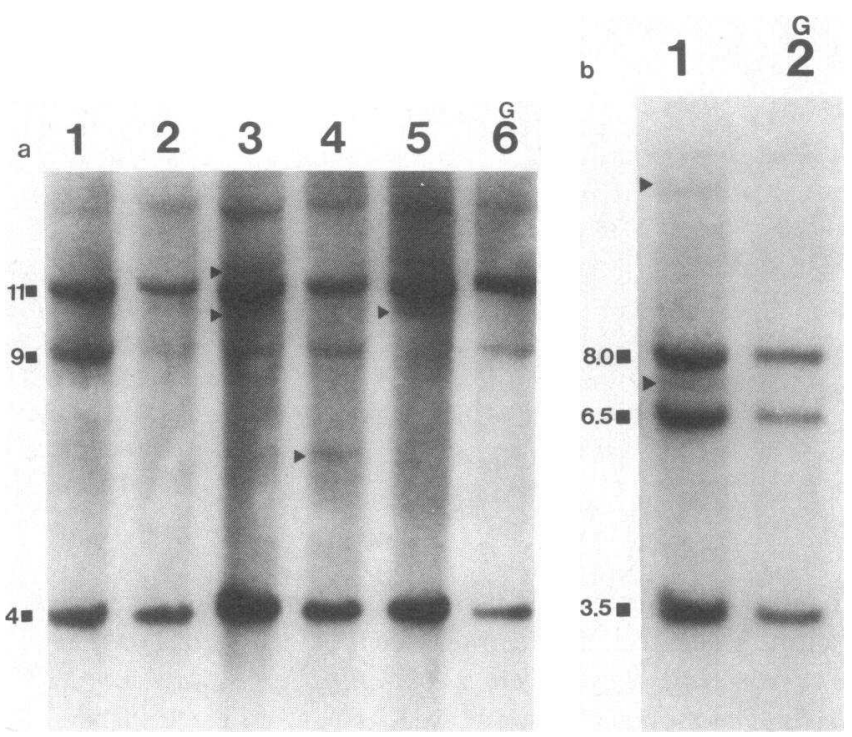

Figure 5. Southern blot of genomic DNA from lymph nodes diagnosed as Hodgkin's disease hybridized with TcR $\beta$. (a) DNA digested with Eco R1. Lanes 1-5, tumor DNA; lane 6, granulocyte DNA. (b) DNA digested with Hind III. Lane 1, tumor DNA; lane 2, granulocyte DNA. $n$, germline band. $\downarrow$, rearranged bands. The molecular weight of the germline band is in kilobases. The probe used in $a$ differs from the probe used in Fig. $3 b$ in that the former probe is contaminated by variable and joining region sequences. This contamination accounts for the extra 14 and $9 \mathrm{~kb}$ germline bands seen in $a$ and not in Fig. $3 b$.

lymphoblastic leukemia (30), chronic lymphocytic leukemia (10), and acute myeloblastic leukemia (31).

Rearrangements of both the Ig and $\mathrm{TcR} \beta$ genes in the same sample may be due to the presence of two different clonal populations of cells, one carrying the Ig rearrangement and the other carrying the $\operatorname{TcR} \beta$ rearrangement, or to both rearrangements co-existing in a single clone of cells. In support of the latter is the observation in present previously reported cases that the intensity of the rearranged TcR and Ig bands are similar. This similarity indicates that the proportion of cells carrying an Ig or TcR rearrangement are identical. In addition, such a genotype has been found in cloned lymphoma cell lines (32) and EpsteinBarr virus-transformed B cells (personal unpublished observation). The co-existence of an Ig and TcR rearrangement may occur in the same cell either as a normal event or as an expression of the disruption of gene regulation that occurs in lymphoma and leukemia cells.

A major diagnostic problem is determining whether $\mathrm{T}$ cells within a hyperplastic lymph node are the malignant cell (as determined by the presence of a monoclonal population of $\mathrm{T}$ cells) or a reactive set of normal cells (as determined by the absence of a monoclonal population of $\mathrm{T}$ cells). In previous studies in which the structure of Ig genes was determined, it was demonstrated that a small clonal population of B cells could be present in lymph nodes containing mainly $T$ cells (6). In the present study we examined two lymphomas in which $50 \%$ of the lymph node was replaced by a pleomorphic population of $T$ cells. In these two samples, rearrangement of the Ig genes but not TcR $\beta$ gene was detected. The lack of a clonal population of $T$ cells in the present study adds experimental support to the previous suggestion that the $\mathrm{T}$ cells are polyclonal in origin and are either 
reacting or responding to a clonal population of malignant $B$ cells.

T lymphocytes also predominate in other lymphomas such as Lennert's lymphoma, $\mathrm{Ki} 1^{+}$lymphomas, AIL, and Hodgkin's disease. Lennert's lymphoma is characterized by the presence of a large number of epithelioid cells, some large lymphoid cells that resemble Reed-Sternberg cells, and a large population of $T$ cells of the T4 helper type. Our study, demonstrating rearrangement of TcR genes in all five samples examined, indicates that there is a predominant monoclonal population of $\mathrm{T}$ cells in Lennert's lymphoma, thus providing further support to the suggestion that Lennert's lymphoma is a T cell malignancy $(3,33,34)$. The finding of two rearranged bands of different intensities in case 5 may be due to the presence of two different clones of $T$ cells. Such biclonality has been identified previously in B cell lymphomas (35) and in Lennert's lymphoma (36).

The $\mathrm{Ki} 1^{+}$monoclonal antibody was raised against a Hodgkin's disease-derived cell line and has been found to react with a variety of cell types including Reed-Sternberg cells, a variable proportion of cells in all cases of lymphomatoid papulosis, AIL in some peripheral $\mathrm{T}$ cell lymphomas, and stimulated normal $T$ cells (37). In addition, the antibody is strongly reactive with tumor cells of a group of diffuse large cell lymphomas with bizarre morphology suggestive of malignant histiocytosis or anaplastic carcinoma. Characterization of these tumors reveals that they lack the markers characteristics of macrophage and epithelial cells and express in a variable manner antigens characteristic of $T$ and $B$ cells.

7 of the 10 samples representing these $\mathrm{Ki} 1^{+}$lymphomas were found to have clonal rearrangement of the $\beta$-chain TcR; in three of these seven samples the Ig heavy chain but not the light chain genes also were found to be rearranged. Again, the intensity of the rearranged bands was consistent with the Ig and TcR rearrangements being present in the same cell population. The finding of a clonal rearrangement of $\operatorname{TcR} \beta$ in most of these cases provides evidence that they are in fact $T$ cell malignancies.

A third disease in which there is a predominance of $\mathrm{T}$ cells is AIL $(25-27,13,38,39)$ and AIL-like HR. In this paper we demonstrate the rearrangement of $\operatorname{TcR} \beta$ chain gene in all cases of AIL examined. In four of these nine cases there was rearrangement of Ig heavy chain genes, and in one of these four cases there was also rearrangement of the $\kappa$-light chain gene. The intensity of the rearranged bands was consistent with the Ig and TcR rearrangements being present in the same population of cells.

AIL-like HR is morphologically similar to AIL. In this lesion there are a large number of immunoblasts, eosinophils, and epithelioid venules. In addition, there are large hyperplastic germinal centers. The prognosis of patients with AIL-like HR is better than the prognosis for patients with AIL. However, in a number of instances, AIL has been seen to develop in patients with AIL-like HR (13). Thus, AIL-like HR may represent an earlier stage of AIL. In the two cases of HR examined in this study no rearrangements were seen; the possible reasons for this are discussed below.

The final disease we studied that has a predominance of $T$ lymphocytes is Hodgkin's disease. The nature of the malignant cell in Hodgkin's disease is controversial. The cells within the lymph node have been classified as monocytes, B cells, $T$ cells, and reticulum cells. In the present study, we found that in four of eight samples with the diagnosis of Hodgkin's disease that there was rearrangement of the $T$ cell $\beta$-chain gene, which in- dicates the presence of a clonal population of $T$ cells. Based on the intensity of the rearranged band, only a small percentage of cells, $(\sim 5 \%)$ are part of the clone. This contrasts with our finding in $B$ cell and $T$ cell lymphomas in which the intensity of the rearranged band indicates that a large proportion of the cells within the lymph node carry the same rearrangement.

It has been suggested that the Reed-Sternberg cell is the malignant cell in the Hodgkin's lymph node. For this reason we compared the intensity of the rearranged bands with the proportion of Reed-Sternberg cells present; no correlation was found. In fact, in one case in which the lymph node consisted of $\sim 50 \%$ Reed-Sternberg cells, no detectable rearrangement was found.

In summary, these studies demonstrate the usefulness of genetic analysis of the TcR $\beta$ chain and Ig genes in the evaluation of proliferative disorders of the lymph node, particularly in demonstrating the presence of a clonal population of $\mathrm{T}$ cells. In the present paper we have described clonal populations of $\mathrm{T}$ cells in Lennerts lymphoma, $\mathrm{Ki} 1^{+}$lymphomas, AIL, and Hodgkins disease. Co-existing rearrangement of the $\operatorname{Ig}$ and $\operatorname{TcR} \beta$ genes was found in AIL and $\mathrm{Ki} 1^{+}$lymphomas.

A number of questions are raised by these findings. First, not all cases of $\mathrm{Ki} 1^{+}$lymphoma and Hodgkins disease contained rearrangements. This may be a result of technical problems such as sampling error and insensitivity of the Southern blot technique or may be due to biologic differences. For example, these diseases, identified by morphologic criteria, may be made up of a number of different entities recognizable by molecular studies. Or these diseases progress over time from a polyclonal proliferation of $\mathrm{T}$ cells to a monoclonal $\mathrm{T}$ cell proliferation. The same arguments may explain the observed differences between AIL and AIL-like HR. Resolving these questions will require longitudinal studies in which clinical, morphologic, immunologic, and molecular approaches are combined.

The second issue requiring further investigation is the finding of $\mathrm{Ig}$ and $\mathrm{TcR} \beta$ rearrangements in the same sample. As has been suggested above, this may be due to the presence of both types of rearrangement in one cell type. However, the present studies have not ruled out the possibility that two populations of cells, one bearing an Ig gene rearrangement, and the other bearing a TcR $\beta$ gene rearrangement, are present. To resolve this issue it will be necessary either to separate the cells into pools of B cells and $T$ cells or to establish cloned lymphoma cell lines from the tumor.

The final issue is the small percentage of clonal $T$ cells in lymph nodes derived from patients with Hodgkin's disease. This finding may be interpreted as evidence that, in some cases, Hodgkin's disease is a disease of malignant or pre-malignant $T$ cells. Alternatively, the clonal population of $\mathrm{T}$ cells may represent a reactive set of normal $\mathrm{T}$ cells responding in monoclonally. Regardless, this initial observation of a clonal population of $\mathrm{T}$ cells in Hodgkin's disease warrants further investigations.

\section{References}

1. Lennert, K. 1973. Pathologisch-histologische Klassifizierung der malignen Lymphome. In Leukamien und maligne Lymphome. A. Stacher, editor. Munchen-Berlin-Wien, Urban \& Schwarzenberg. 181194.

2. Stein, H., K. Lennert, A. C. Feller, and D. Y. Mason. 1984. Immunohistological analysis of human lymphoma: correlation of histological and immunological categories. Adv. Cancer Res. 42:67-147.

3. Lukes, R. J., J. W. Parker, C. R. Taylor, B. H. Tindle, A. D. 
Cramer, and T. L. Lincoln. 1978. Immunologic approach to non-Hodgkin's lymphomas and related leukemias. Analysis of the results of multiparameter studies of 425 cases. Semin. Hematol. 15:322-351.

4. Korsmeyer, S. J., P. A. Hieter, J. V. Ravetch, T. A. Poplack, T. A. Waldmann, and P. Leder. 1981. Developmental hierarchy of immunoglobulin gene rearrangements in human leukemic pre B-cells. Proc. Natl. Acad. Sci. USA. 78:7096-100.

5. Korsmeyer, S. J., A. Arnold, A. Bakhski, J. V. Ravetch, U. Siebenlist, P. A. Heiter, S. O. Sharrow, T. W. LeBien, J. H. Kersey, D. G. Poplack, P. Leder, and T. A. Waldmann. 1983. Immunoglobulin gene rearrangement and cell surface antigen expression in acute lymphocytic leukemias of T cell and B cell precursor origins. J. Clin. Invest. 71:301313.

6. Arnold, A., J. Cossman, A. Bakhshi, E. S. Jaffe, T. A. Waldmann, and S. J. Korsmeyer. 1983. Immunoglobulin-gene rearrangements as unique clonal markers in human lymphoid neoplasms. $N$. Engl. J. Med. 309:1593-1599.

7. Yanagi, Y., Y. Yoshkkai, K. Leggett, S. Clark, I. Aleksander, and T. Mak. 1984. A human T-cell specific cDNA clone encodes a protein having extensive homology to immunoglobulin chains. Nature (Lond.). 308:145-149.

8. Minden, M. D., B. Toyonaga, K. Ha, Y. Yanagi, B. Chin, E. Gelfand, and T. Mak. 1985. Somatic rearrangement of T-cell antigen receptor gene in human T-cell malignancies. Proc. Natl. Acad. Sci. USA. 82:1224-1227.

9. O'Connor, N. T. J., J. S. Wainscoat, D. J. Weatherall, K. C. Gatter, A. C. Feller, P. Isaacson, D. Jones, K. Lennert, G. Pallesen, A. Ramsey, H. Stein, D. H. Wright, and D. Y. Mason. 1985. Rearrangement of the T-cell receptor $\beta$-chain gene in the diagnosis of lymphoproliferative disorders. Lancet. 1:1295-1297.

10. Waldmann, T. A., M. M. Avis, K. F. Bongiovanni, and S. J. Korsmeyer. 1985. Rearrangements of genes for the antigen receptor of T cells as markers of lineage and clonality in human lymphoid neoplasms. N. Engl. J. Med. 313:776-783.

11. Kitchingman, G. R., U. Rovigatti, A. M. Mauer, S. Melvin, S. B. Murphy, and S. Stass. 1985. Rearrangement of immunoglobulin heavy chain genes in T cell acute lymphoblastic leukemia. Blood. 65: 725-729.

12. Pelicci, P.-G., D. H. Knowles, II, and R. D. Favera. 1985. Lymphoid tumors displaying rearrangements of both immunoglobulin and T cell receptor genes. J. Exp. Med. 162:1015-1024.

13. Knecht, H., E.-W. Schwarze, and K. Lennert. 1985. Histological, immunohistological and autopsy findings in lymphogranulomatosis $\mathbf{X}$ (including angio-immunoblastic lymphadenopathy). Virchows Arch. Pathol. Anat. Physiol. K. M. 406:105-124.

14. Stein, H., K. Lennert, A. Feller, and D. Y. Mason. 1984. Immunohistological analysis of human lymphomas. Adv. Cancer Res. 42: 67-141.

15. Gusella, J. F., E. Keyes, A. Versanyi-Bryner, F. T. Kao, C. Jones, T. T. Puck, and D. Housman. 1980. Isolation and localization of DNA segments from specific human chromosomes. Proc. Natl. Acad. Sci. USA. 77:2829-2833.

16. Southern, E. M. 1975. Detection of specific sequences among DNA fragments separated by gel electrophoresis. J. Mol. Biol. 98:503517.

17. Ravetch, J. V., U. Siebenlist, S. J. Korsmeyer, T. A. Waldmann, and P. Leder. 1981. The structure of the human immunoglobulin mu locus: characterization of embryonic and rearranged $\mathrm{J}$ and $\mathrm{D}$ genes. Cell. 27:583-591.

18. Hieter, P. A., E. E. Max, J. G. Seidman, J. F. Maizel, and P. Leder. 1980. Cloned human and mouse kappa immunoglobulin constant and $\mathrm{J}$ region genes conserve homology in functional segments. Cell. 22: 197-207.

19. Yoshikai, Y., D. Anatoniou, S. P. Clark, Y. Yanagi, R. Sangster, P. Van de Elsen, C. Terhorst, and T. W. Mak. 1984. Sequence and expression of transcripts of the human T-cell receptor $\beta$-chain genes. Nature (Lond.). 312:521-524.
20. Rigby, P. J., M. Dieckman, C. Rhodes, and Q. Berg. 1977. Labeling deoxyribonucleic acid to high specific activity in vitro by nick translation with DNA polymerase I. J. Mol. Biol. 113:237-251.

21. Lennert, K. 1952. Zur histologischen Diagnose der Lymphogranulomatose. Habil.-Schrift, Frankfurt.

22. Lennert, K., and J. Mestdagh. 1968. Lymphogranulomatosen mit konstant hohem Epitheloidzellgehalt. Virchows Arch. Pathol. Anat. Physiol. K. M. 344:1-20.

23. Stein, H., D. Y. Mason, J. Gerdes, N. O'Connor, J. Wainscoat, G. Pallesen, K. Gatter, B. Falini, G. Delsol, H. Lemke, R. Schwarting, and K. Lennert. 1985. The expression of the Hodgkin's disease associated antigen $\mathrm{Ki}-1$ in reactive and neoplastic lymphoid tissue: evidence for a relationship between Reed-Sternberg cells polymorphic large cell lymphomas. Blood. 66(4):848-858.

24. Frizzera, G., E. M. Moran, and H. Rappaport. 1974. Angioimmunoblastic lymphadenopathy with dysproteinaemia. Lancet. 1:10701073.

25. Lukes, R. J., and B. H. Tindle. 1975. Immunblastic lymphadenopathy: a hyperimmune entity resembling Hodgkin's disease. $N$. Engl. J. Med. 292:1-8.

26. Radaszkiewicz, T., and K. Lennert. 1975. Lymphogranulomatosis $\mathrm{X}-\mathrm{Klinisches}$ Bild, Therapie und Prognose. Deut. Med. Wochenschr. 100:1157-1163.

27. Shimoyama, M., K. Minato, H. Saito, T. Takenaka, S. Watanabe, T. Nagatani, and M. Naruto. 1979. Immunoblastic lymphadenopathy (IBL)-like T-cell lymphoma. Jpn. J. Clin. Oncol. 9(Suppl. 1):347-356.

28. Hossfeld, D. K., K. Hoeffgen, C. G. Schmidt, and H. Diedrichs. 1976. Chromosome abnormalities in angioimmunoblastic lymphadenopathy. Lancet. 1:198.

29. Kaneko, Y., R. A. Larson, D. Variakojis, J. M. Haren, and J. D. Rowley. 1982. Nonrandom chromosome abnormalities in angioimmunoblastic lymphadenopathy. Blood. 60:877-887.

30. Tawa, A., N. Hozumi, M. Minden, T. W. Mak, and E. W. Gelfand. 1985. Rearrangement of the T-cell receptor $\beta$-chain gene in non-T, nonB acute lymphoblastic leukemia of childhood. N. Engl. J. Med. 313: 1033-1037.

31. Cheng, G. Y., M. D. Minden, B. Toyonaga, T. W. Mak, and E. A. McCulloch. 1986. T cell receptor and immunoglobulin gene rearrangements in acute myeloblastic leukemia. J. Exp. Med. 163:414.

32. Kronenberg, M., G. Siu, L. E. Hood, and N. Shastri. 1986. The molecular genetics of the T-cell antigen receptor and T-cell antigen recognition. Annu. Rev. Immunol. 4:529-591.

33. Lennert, K., N. Mohri, H. Stein, and E. Kaiserling. 1975. The histopathology of malignant lymphoma. Br. J. Haematol. 31(Suppl.): 193-203.

34. Lennert, K., and A. C. Feller. 1985. Morphology and immunohistology of $\mathrm{T}$ cell lymphomas. In The cytobiology of leukemias and lymphomas. Vol. 20. D. Quaglino and F. G. J. Hayhoe, editors. Raven Press, New York. 81-90.

35. Siegelman, M. H., M. L. Cleary, R. Warnke, and J. Sklar. 1985. Frequent biclonality and Ig gene alterations among $\beta$ cell lymphomas that show multiple histologic forms. J. Exp. Med. 161:850-863.

36. Godde-Salz, E., and E.-W. Schwarze. 1984. Biclonal trisomy 3 in a case of epithelioid cellular Lymphogranulomatosis (Lennert's Lymphoma). Cancer Genet. Cytogenet. 13:337-341.

37. Schwab, U., H. Stein, J. Gerdes, H. Lemke, H. Kirchner, M. Schaadt, and V. Diehl. 1982. Production of a monoclonal antibody specific for Hodgkin and Sternberg-Reed cells of Hodgkin's lymphoma and a subset of normal lymphoid cells. Nature (Lond.). 299:65-67.

38. Knecht, H., and K. Lennert. 1981a. Vorgeschichte und klinisches Bild der Lymphogranulomatosis X (einschließlich (angio) immunoblastischer Lymphadenopathie). Schweiz. Med. Wochenschr. 111:1108-1121.

39. Knecht, H., and K. Lennert. 1981b. Verlauf, Therapie und maligne Transformation der Lymphogranulomatosis X (einschlie $\beta$ lich (angio) immunoblastischer Lymphadenopathie). Schweiz Med Wochenschr. 111:1122-1130. 